\title{
FAULTING AND SUBSIDENCE DURING THE EDGECUMBE EARTHQUAKE, MARCH 2, 1987, NEW ZEALAND
}

\author{
Rodney H. Grapes* \\ Research School of Earth Sciences, \\ Victoria University of Wellington, \\ Private Bag, Wellington, New Zealand
}

(Received August 27)

\begin{abstract}
A M 6.3 earthquake occurred on March 2nd 1987 beneath the Rangitaiki Plain at the NE end of the Central Volcanic Zone, North Island, New Zealand. Surface faulting and regional subsidence of up to $2 \mathrm{~m}$ are consistent with shallow depth (about $12 \mathrm{~km}$ ) extensional normal faulting. The most prominent rupture developed along a previously unrecognized active fault trace over a distance of $7 \mathrm{~km}$ with maximum vertical displacement of $1.5 \mathrm{~m}$ and extension of about $1.2 \mathrm{~m}$. The vertical movement almost doubled the height of the pre-earthquake scarp. Compressional features developed on either side of the main rupture and many sand fountains were erupted over the area of regional subsidence where the water table was near the surface. Continuity of stratigraphy across the main fault which contains tephra layers and pumice alluvium indicates that possibly two faulting events took place prior to $1.8 \mathrm{Ky}$ B.P. with the same sense of movement as the March 2nd earthquake. Buried tephras and $6.5 \mathrm{Ky}$ shells indicate an average subsidence rate of about $2 \mathrm{~mm} / \mathrm{yr}$ over this period for the same area that underwent subsidence during the latest event. The effects of the March 2nd earthquake and previous earthquakes are consistent with the extension that is taking place across the Central Volcanic Zone.
\end{abstract}

\section{Introduction}

An earthquake of $M 6.3$ occurred at $01 \mathrm{hr} 42 \mathrm{~m} 34 \mathrm{~s}$ UT on March 2nd 1987 about $12 \mathrm{~km}$ beneath the Rangitaiki Plain which marks the NE end of the Central Volcanic Zone of the North Island of New Zealand. The earthquake caused surface faulting and tectonic subsidence over virtually the whole of the Rangitaiki Plain area. While faulting took place on some previously existing faults, other ruptures may be the result of compaction of the soft sediments underlying the plain. In addition, widespread liquefaction of alluvium underlying the area resulted in the

* Now at the Department of Earth Science, Ehime University, Matsuyama, Shikoku, Japan 
eruption of many sand fountains. Small scale landslides occurred within pumiceous rocks that border the plain along its NW side. Although there was considerable damage to property there were no fatalities. Because the area affected by the earthquake is almost flat, only a few meters above sea level, and covered with grass, conditions are ideal for showing faulting and related phenomena which could be studied in detail. This study was considerably aided by complete air photo coverage of the damaged area completed a few days after the earthquake. The March 2nd earthquake affected an area which had no record of such deformation over the past 100 years or so and where previously existing fault traces had not been recognized.

\section{Regional Setting}

The Rangitaiki Plain is situated at the NE end of the Central Volcanic Zone in the North Island of New Zealand (Fig. 1). It is underlain by unconsolidated sands, silt, peat and gravel of Pleistocene-Holocene age. The uppermost $10 \mathrm{~m}$ of sediment are less than $6.5 \mathrm{Ky}$ old and contain post $6 \mathrm{Ky}$ volcanic ash layers. To the west the plain is bounded by low hills composed of pumiceous deposits of

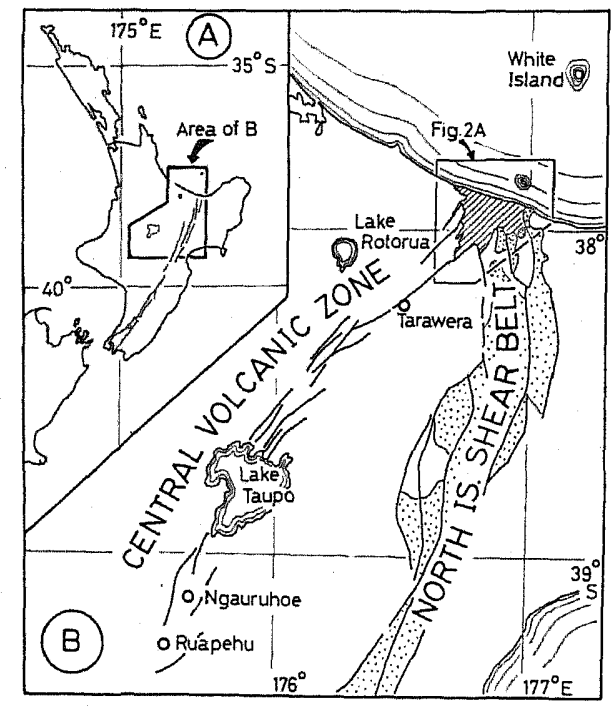

Fig. 1. North Island location map (A) and map (B) showing the zone of active normal faults of the Central Volcanic Zone graben and the active dextral faults of the North Island Shear Belt which intersect beneath the Rangitaiki Plain (hachured area). The Central Volcanic Zone extends from the active andesite volcanoes of Ngauruhoe and Ruapehu in the south to White Island in the north. Dotted areas are outcrops of Mesozoic greywacke. An eruption from Lake Taupo 1800 yr B.P. resulted in the deposition of pumice alluvium over most of the Rangitaiki Plain area that was later mantled by ash erupted from Mount Tarawera in 1886 and $700 \mathrm{yr}$ B.P. See text for explanation. 
Quaternary age, and to the east by a range of Mesozoic greywacke which is transected by active faults of the North Island Shear Belt (Fig. 1) with an average rate of dextral movement of about $15 \mathrm{~mm} / \mathrm{yr}$. Although the faults of the North Island Shear Belt intersect a NNE striking zone of normal faults related to graben formation along the Central Volcanic Zone beneath the Rangitaiki Plain (Fig. 1), no active faulting had been recorded in the area prior to the March 2 nd earthquake.

\section{Faulting}

Several fault ruptures occurred during the earthquake all of which have a NE strike (Fig. 2). The most spectacular rupture is situated to the east of Edgecumbe Town, extends over a distance of $7 \mathrm{~km}$, and in places is up to $4 \mathrm{~m}$ deep and up to $3 \mathrm{~m}$ wide (Figs. 3, 4(A) and (B)). One person observed the formation of the rupture which propagated from north to south. Prior to the earthquake the line along which the rupture occurred was a $2 \mathrm{~m}$ high embankment downthrown to the NW. Because this embankment was rather irregular (Fig. 3) it was not recognized as an active fault. During the March 2nd event faulting took place along the entire length of this embankment. The amount of vertical displacement that occurred during the earthquake varied along the fault from 0.5 to $1.5 \mathrm{~m}$ with

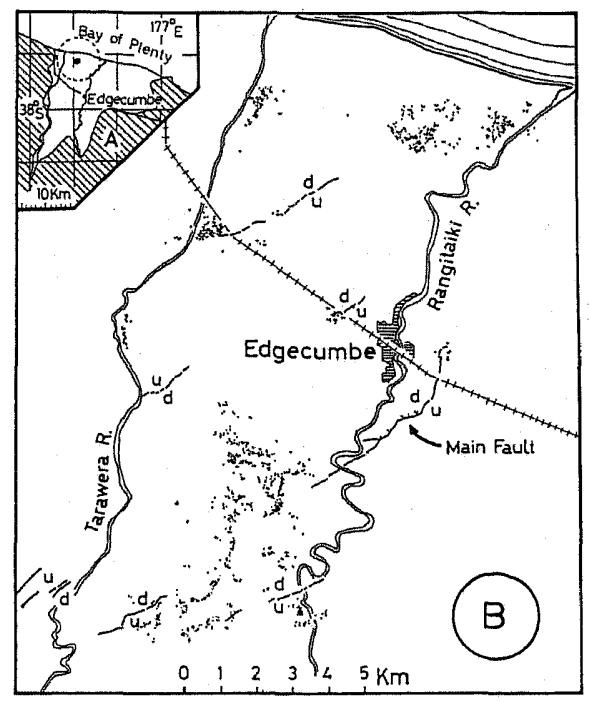

Fig. 2. Location map (A) and map showing the distribution of faulting and sand fountains resulting from the March 2 nd earthquake (B). In (A) the filled circle indicates the epicenter of the March 2nd earthquake $\pm 5 \mathrm{~km}$ (radius of dashed line circle). In (B) the faults are labelled with the sense of movement: $d$, downthrown side; $u$, upthrown side. Dots represent individual sand fountain deposits and minor slip scars in the grassy surface of the plain and were plotted from air photos taken soon after the earthquake. 


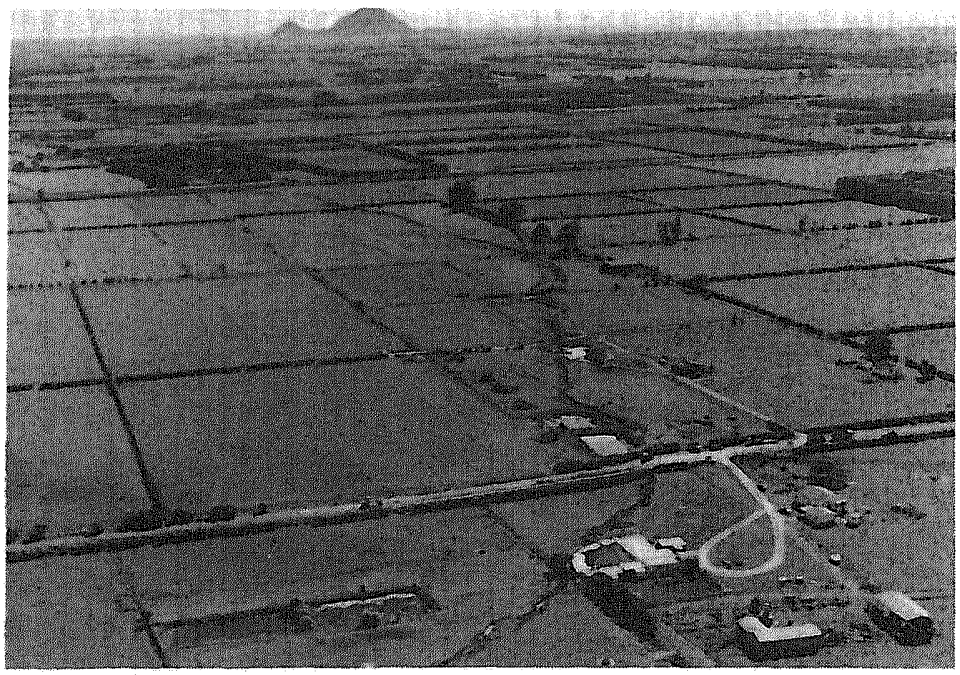

Fig. 3. Oblique aerial photo of the main fault trace that ruptured during the March 2nd earthquake viewed towards the NE. Note the irregular line of the rupture which followed along the crest of a low embankment that existed prior to the earthquake and which was not recognized as the scarp of an active fault. (Original photo by D. L. Homer, New Zealand Geological Survey).
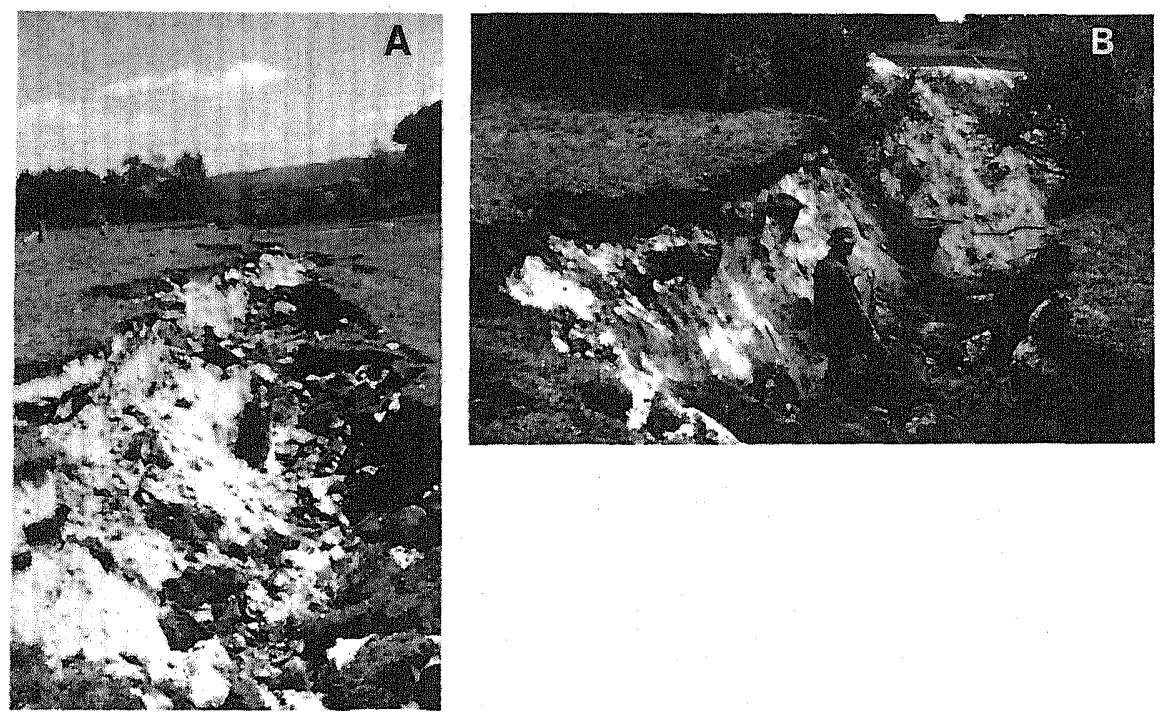

Fig. 4. Photos A and B show the nature of rupturing along the main fault. In these areas, near the middle part of the fault, the width of the trench is about $3 \mathrm{~m}$ due to the caving in of the near vertical side walls. The white material exposed in the walls of the trench is rhyolitic pumice alluvium derived from an eruption from Lake Taupo $1800 \mathrm{yr}$ B.P. The stratigraphy across this part of the fault is given in Fig. 8 . 
the maximum displacement near the middle part. Vertical movement appears to have resulted from the upheaval of the ground surface to form a monoclinal flexure up to $40 \mathrm{~m}$ wide with rupturing taking place along the crest of the flexure. The flexure is most pronounced near the middle of the fault where the greatest vertical movement is recorded. Towards the ends of the fault the flexure flattens out and the amount of vertical movement drops to less than $0.5 \mathrm{~m}$. Extension across the fault amounted to between 1.0 and $1.4 \mathrm{~m}$ and was in a NW direction. Although in several places the width of the rupture reaches $3 \mathrm{~m}$ this has resulted from caving in of the nearly vertical walls (Fig. 4(A) and (B)). Along those sections of the fault that have a more northerly strike (Fig. 2), between $20-30 \mathrm{~cm}$ of apparent dextral movement was measured from displaced fence lines and concrete paths that cross the fault.
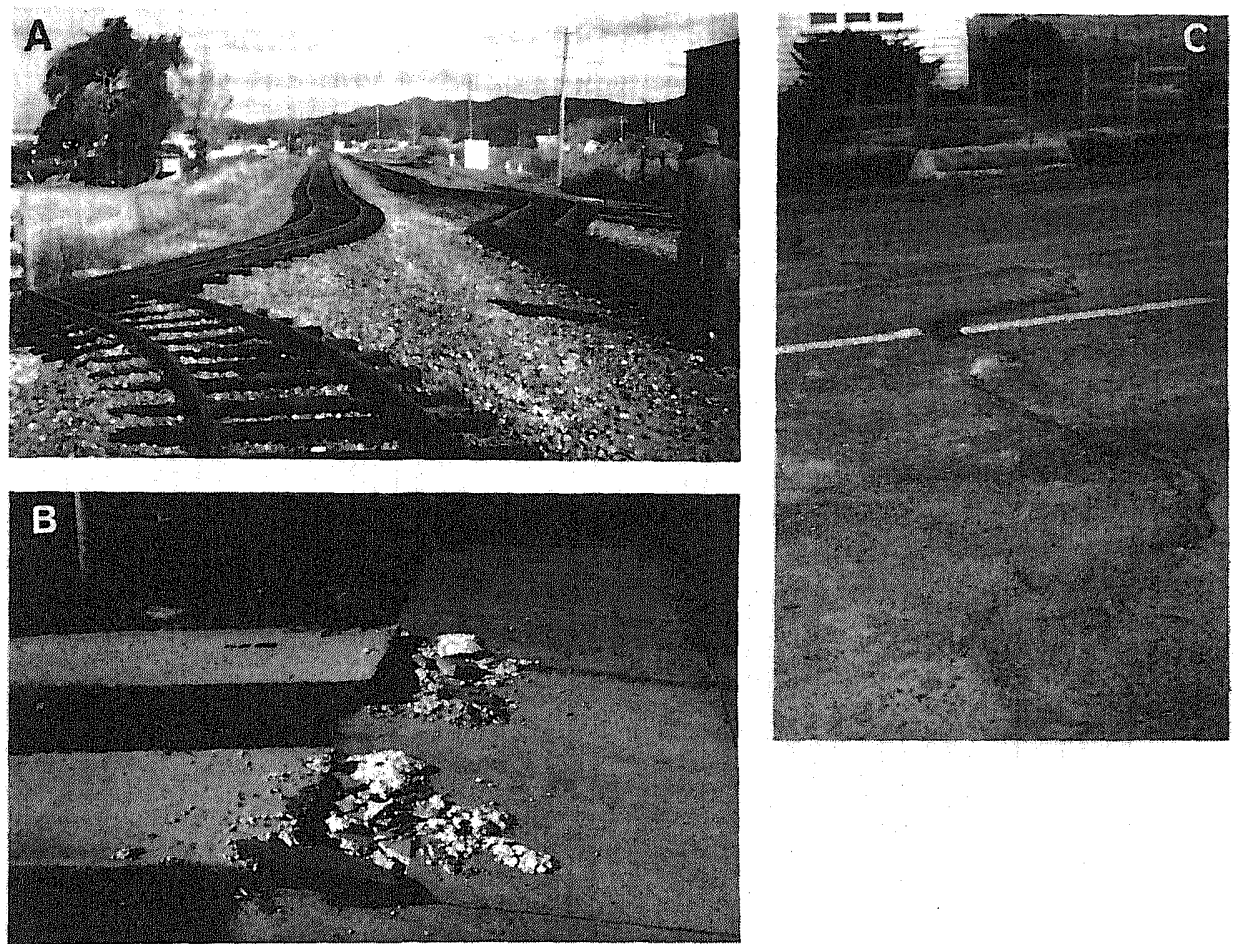

Fig. 5. Photos of some compression features in Edgecumbe Town that resulted from the March 2nd earthquake. (A) Bent railway lines at Edgecumbe Station looking west. The amount of bending in the right railway line indicates compression of between 1-2m. The left railway line, plus wooden sleepers, has been moved sideways off the gravel embankment and has been broken. (B) Concrete pads of a driveway overthrust onto a footpath along the join. Note also that the footpath has been tilted. (C) A compressional role developed in the main asphalt sealed road that runs parallel to the railway line through Edgecumbe. Most of such features were developed normal to the center line on the road. 
Six other faults formed during the earthquake and are distributed to the west of the main fault. They vary from 0.5 to about $4 \mathrm{~km}$ in length and have vertical displacements of between 0.2 and $1 \mathrm{~m}$. In most cases the downthrown side is to the NW but on two faults displacement is in the opposite sense (Fig. 2).

Extension along the main fault was associated with compression taking place on both sides of the fault. Compressional features (Fig. 5(A), (B), and (C)) were: buckled and broken railway lines; compressive waves traversing asphalt-covered roads; broken and upthrust underground water, gas, and sewer pipes; overthrust concrete features along joins in roadsides and driveways. Compression of the railway lines at Edgecumbe Station west of the main fault was of the order of 1-2 $\mathrm{m}$ (GRAPES et al., 1987) and that on the same railway line east of the main fault amounted to about $25 \mathrm{~cm}$. All these features were arranged with the compressional axis approximately in a NW-SE direction and were most apparent within two zones trending NE-SW on either side of the main fault.

\section{Sand Fountains}

Innumerable white volcanic sand fountains erupted onto the grassy surface of the plain during the earthquake, particularly where the water table existed at a

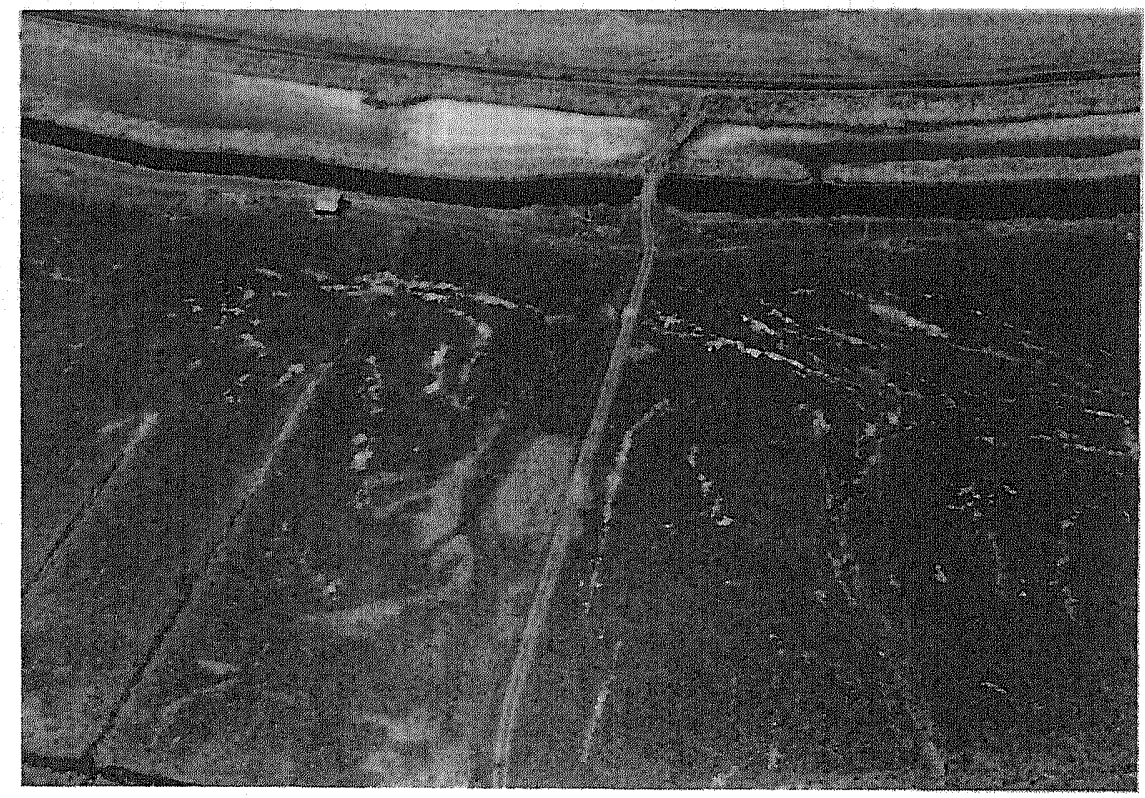

Fig. 6. Aerial photo of conspicuous white volcanic sand fountain deposits that were erupted onto grass-covered farmland during the March 2nd earthquake. (Original photo by D. L: Homer, New Zealand Geological Survey). 
shallow depth (Fig. 6). The distribution of the sand fountains is shown in Fig. 2 and they were very conspicuous on the air photos taken soon after the earthquake. They subsequently disappeared within a few weeks due to rain and farming activity. Sand fountaining was confined to the area of tectonic subsidence that occurred during the earthquake (see below), i.e. to the west of the main fault. Although they do not appear to show any significant relationship to the distribution of surface faulting the en-echelon arrangement of sand fountains and surficial slips to the south of the main fault rupture may indicate its underground extension.

\section{Tectonic Subsidence}

Repeat second order levelling of bench marks over the Rangitaiki Plain shortly after the earthquake indicated subsidence of an area of about $5 \mathrm{~km}$ on either side of an axis trending N-S over a distance of at least $20 \mathrm{~km}$. The results of elevation differences between pre- and post-earthquake surveys, together with vertical displacement across the faults, are utilized in the construction of Fig. 7(A) and the cross-section profiles in Fig. 7(B). The most spectacular feature was the formation of a deep depression (up to $2 \mathrm{~m}$ deep) centered on the downthrown side of the middle part of the main fault. Buried $5.2 \mathrm{Ky}$ tephra and $1.8 \mathrm{Ky}$ pumice alluvium together with a shell/gravel horizon inferred to be the $6.5 \mathrm{Ky}$ sea level give a subsidence rate for the area west of the main fault of between 1.8 and $2.5 \mathrm{~mm} / \mathrm{yr}$. To the east of the fault subsidence has been at about half this rate (e.g., Pullar, 1981). This pattern indicates continuity of ground deformation, such as that which occurred during the March 2nd earthquake, extending back at least $6.5 \mathrm{Ky}$ B.P.

\section{Previous Faulting}

The stratigraphy across the middle part of the main fault is illustrated in Fig. 8. This indicates that layers above the $1.8 \mathrm{Ky}$ Taupo pumice alluvium follow the slope of the flexure over the fault with thickening of individual layers towards the downthrown side. From this evidence it is inferred that there has been no earthquake movement on the main fault since at least $1.8 \mathrm{Ky}$ ago and that the height difference across the scarp existing prior to the March 2 nd event had been reduced due to smoothing as a result of soil flow from the upthrown to the downthrown side. The height of the fault scarp before the earthquake was about $1.5-2.0 \mathrm{~m}$. Displacement during the earthquake almost doubled this height difference. Therefore the pre-earthquake scarp was probably the result of one, possibly two, earthquakes of similar magnitude prior to the deposition of the Taupo pumice alluvium $1.8 \mathrm{Ky}$ B.P.

\section{Conclusion}

The pattern of surface faulting, particularly that of the main fault and regional 


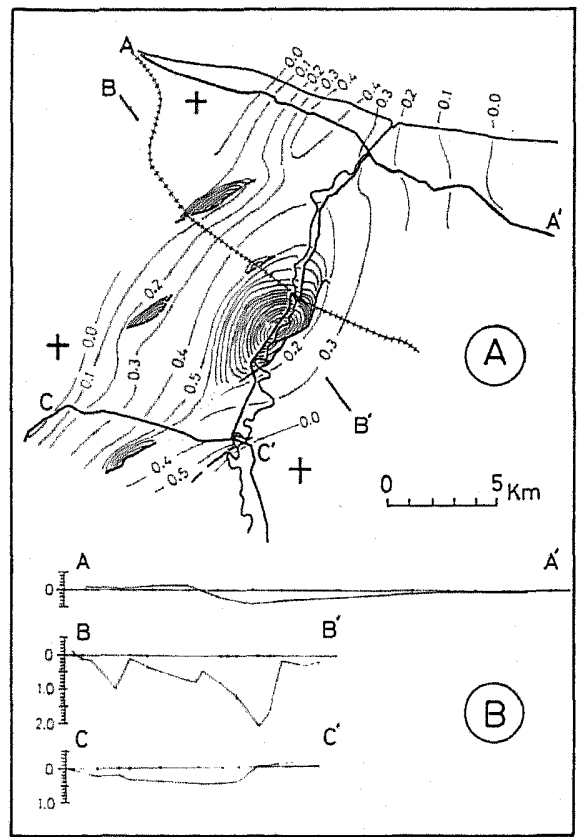

Fig. 7. (A) Contour map of subsidence that occurred over the Rangitaiki Plain during the March 2nd earthquake. 0.1 contour line, etc., $0.1 \mathrm{~m}$ subsidence; 0.0 , no height change between pre and post earthquake surveys; + , areas where uplift $(<+0.1 \mathrm{~m})$ occurred. Thick lines indicate survey routes along which the bench marks are located. Basic levelling data from the Bay of Plenty Catchment Commission (April, 1987). (B) Cross sections A-A', B-B', and C-C' are plotted showing height difference between pre and post earthquake survey of bench marks. Each division, $0.1 \mathrm{~m} ; 0$ position, no height change.

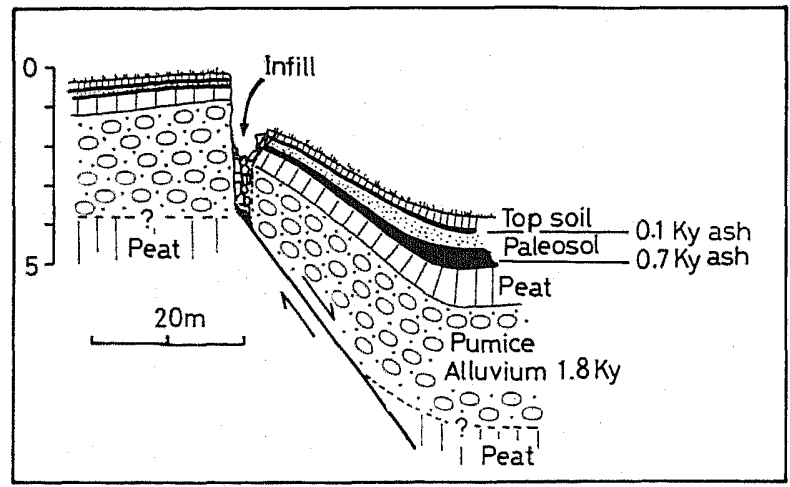

Fig. 8. Representative section across the middle part of the main fault shown in Fig. 4(A). The dip of the fault plane is inferred (after Grapes et al., 1987) as is the displacement of the peat layer beneath the pumice alluvium. 
subsidence indicates that the March 2nd earthquake resulted from shallow depth extensional normal faulting. The earthquake was the latest of possibly two earlier earthquakes that occurred prior to $1.8 \mathrm{Ky}$ B.P. with the same sense of movement. The events are consistent with the extension across the whole of the Central Volcanic Zone which is taking place at $7 \pm 3 \mathrm{~mm} / \mathrm{yr}$ according to retriangulation measurements (GRAPES et al., 1987).

I would like to thank Mr. G. A. Dick, Bay of Plenty Catchment Commission and Regional Water Board, Whakatane, for supplying me with a location map and summary of second order levelling done by the Lands and Survey Department following the March 2nd earthquake. My thanks are also due to Dr. Simon Lamb of the Research School of Earth Sciences, Victoria University of Wellington for the photos that are reproduced in Figs. 4 and 5 of this paper.

\section{REFERENCES}

Grapes, R. H., B. Sissons, and H. W. Wellman, Widening of the Taupo Volcanic Zone, New Zealand, and the Edgecumbe Earthquake of March, 1987, Geology, 15, 1123-1 125, 1987.

PULLAR, W. A., Recent earth movements in Whakatane graben suggested by tephra markers and surficial deposits, in Proceedings of Tephra Workshop, June 30th-July 1st, 1980, Victoria University of Wellington, ed. R. Howarth, P. Froggatt, C. G. Vucetich, and J. D. Collen, No. 20, pp. 110-113, Publication of Geology Department Victoria University Wellington, Wellington, 1981. 